\title{
ALEGORIE I SYMBOLE PROLETARIATU. RETORYKA ODPODMIOTOWIENIA I UPODMIOTOWIENIA KLASY ROBOTNICZEJ W TEKSTACH POETYCKICH DRUGIEJ POŁOWY XIX WIEKU ${ }^{1}$
}

Słowa kluczowe: ekonomia literatury, poezja rewolucyjna, proletariat w literaturze, symbol, alegoria Keywords: economy of literature, revolutionary poetry, proletariat in literature, symbol, allegory

W artykule zostaną omówione dwa modele przedstawienia proletariatu w poezji drugiej połowy XIX wieku. Pierwszy model odwołuje się do obrazu nędzy, biedy, słabości. Zwykle pokazuje słabe jednostki (dzieci, sieroty, nędzarzy) postawione wobec aparatu państwowego albo wobec braku pomocy ze strony otoczenia. W tym modelu bardzo często pojawiają się różne formy alegoryczne. Drugi model pojawia się w tzw. poezji rewolucyjnej ${ }^{2}$. Tu obraz nędzy, słabości zaczyna odgrywać zupełnie inną rolę - nędzę proletariatu obserwuje nie zewnętrzny obserwator, lecz ma ją dostrzec sam proletariat, ale tylko po to, by zaraz zobaczyć siłę słabych wynikającą z ich liczebności. Ta sama rzeczywistość zostaje zatem ujęta w zupełnie inny sposób - w pierwszym przypadku chodzi o obraz potwierdzający nędzę i słabość proletariatu, którą może zmienić tylko interwencja zewnętrznego filantropa, a w drugim o wywołanie poczucia siły proletariatu, który - choć słaby, wyzyskiwany, poniżony - ma w sobie moc wydobycia się ze swojego położenia.

Zmiana dokonuje się oczywiście w przedstawianych treściach, ale dotyka też formy wiersza - przede wszystkim sposobów organizacji perspektywy i czasu, retoryki czasowości. W pierwszym przypadku dominuje perspektywa zewnętrzna: historie nędzarzy przedstawione są przez kogoś, kto sam nędzarzem nie jest,

${ }^{1}$ Artykuł powstał w ramach projektu „Ekonomia literatury”. Projekt został sfinansowany ze środków Narodowego Centrum Nauki przyznanych na podstawie decyzji nr DEC-2012/05/D/HS2/03589.

${ }^{2}$ Vide Tadeusz Bujnicki, O poezji rewolucyjnej. Szkice $i$ sylwetki (Katowice: Wydawnictwo „Śląsk”, 1978). 
skierowane także do innych grup społecznych niż proletariat. Te historie często konfrontują jednostkowe losy biedaków z ogólną, alegoryczną nędzę - do niej kierują się apostrofy, czasem sama Nędza staje się bohaterką. Podkreślana przez Paula de Mana czasowa odległość ${ }^{3}$ alegorii od swojego początku uwypukla tu dystans między nędzą a jej przedstawieniem.

Całkiem inaczej dzieje się w poezji rewolucyjnej, gdzie dystans znika, a ujawnia się dążenie do zapętlenia czasu teraźniejszej nędzy i przyszłej potęgi nędzarzy, jakby w każdym momencie powstawania świadomości zbiorowej siły i jej manifestacji (np. w czasie pochodu), już uobecniał się czas rewolucji, już dochodziło do przemiany nędzarzy w ludzi odzyskujących swoją godność. By można było wyrazić aktualną obecność przyszłej siły, dochodzi do przemiany formy literackiej, która wykorzystuje logikę symbolu jako połączenia różnych czasów w jedno doświadczenie.

Artykuł opowiada zatem historie politycznej przemiany literackiej formy. Poetyka alegorii pozwala pisarzom wywołać efekt przemożnej siły nędzy - traktowanej jako autonomiczny podmiot, który wyniszcza życie kolejnych pokoleń biedaków. Symboliczna poetyka poezji rewolucyjnej - odwołując się przecież do tej samej sytuacji, a czasem nawet do tych samych motywów literackich - przemieszcza akcent z siły autonomicznej nędzy na siłę nędzarzy.

\section{Alegorie nędzy, nędza alegorii}

Podstawowy sposób konstrukcji obrazu proletariatu odwoływał się do historii potwierdzających robotniczą biedę, nędzę, chorobę. Taki obraz dominować będzie w poezji Marii Konopnickiej i Antoniego Pileckiego, którzy raczej nie skupiają się na „przeciętnych” robotnikach, a na jednostkach w stanie upadku, życiowej katastrofy, niepewności. Różne historie (lumpen-)proletariuszy zestawiane będą z wywodzonymi z różnych tradycji alegorii nędzy, biedy, niedostatku. Nie chciałbym tu dokładnie opisywać przywoływanych obrazów alegorycznych, a raczej - poprzez analizę wybranych przykładów działania nędzy - uchwycić model konceptualizacji biedy jako osobnego bytu istniejącego poza biedakami. Zamiast przedstawienia różnych personifikacji nędzy, chciałbym skupić się na określeniu ich funkcji w myśleniu o klasach zależnych.

Wiersz Przed sądem, otwierający zbiór Poezji Pileckiego ${ }^{4}$, napisany został jako mowa obrończa robotnika, który mimo że nie zdobył wykształcenia, gdyż bieda „wygnała” go do pracy, osiągnął życiową stabilizację, założył rodzinę, czuł się szczęśliwy i radosny, ale po redukcji w fabryce przechodzi kolejne stopnie

${ }^{3}$ Paul de Man, „Retoryka czasowości”, trans. Andrzej Sosnowski, Literatura na Świecie, no. 10-11 (1999): 215.

${ }^{4}$ Antoni Pilecki, Poezye (Kraków: nakł. W. Poturalskiego, 1892). 
degradacji - od płaczu, żalu, gniewu i chęci zemsty, przez głód i żebranie, upokorzenia, aż do kradzieży i aresztowania. Robotnik z wiersza Pileckiego traktuje swoją historię jako typowy los, mówi: „dzieje moje zwykłe, jak dzieje tysięcy” i w wierszach Pileckiego takich historii będzie może nie tysiące, ale na pewno dziesiątki. Wiersz Za ostatni grosz ${ }^{5}$ otwiera apostrofa do nędzy:

Nędzo! ty blada maro! straszna trucicielko!

Sępie krwawy, z serc ludzkich ssący krwi ostatki!

Szatanie, co wydzierasz dziecię z objęć matki!

Nędzo! ty jesteś siłą potężną i wielką -

W ogniach piekła zrodzoną i straszną jak piekło!...

[...]

Nędzo! największy z wrogów ludzkości cierpiącej!

Kiedyż cię światło wieków w ciemnościach zagrzebie?!

Pilecki odrywa uwagę od sytuacji poetyckich bohaterów, by odwołać się do upodmiotowionej, alegorycznej nędzy. Przywołanie serii obrazów mary, trucicielki, sępa, szatana, siły i wroga otwiera katalog tradycyjnych wizualizacji biedy, które w wierszu zgodnie łączą się w opozycji do przygniatanego nędzą biedaka. Podkreślana potęga i wielkość nie wiążą się tu z potencjalną siłą nędzarzy, a siłą samej nędzy, zdolnej do poniżenia wielkich grup ludzkości. Społeczny problem biedy zostaje zatem przesunięty w pole rozważań historiozoficznych czy metafizycznych.

Do podobnej alegoryzacji dochodzi w Nędzy. Alegorii społecznej Włodzimierza Stebelskiego ${ }^{6}$, który opowiada historię Marii Nędzy, doświadczającej w swoim życiu głównie głodu. Maria spotyka uczonego męża, badacza nędzy chcącego z niej zrobić „archetyp ludzkiej rasy”, ale na wołanie „chleba dla głodnego ciała”, oburza się, „że wołaniem groźnem, mglistem / śmie społeczny drażnić system!”. Granicę akceptacji nędzy stanowi jej milczenie, brak głosu domagającego się pomocy - nędza powinna w ciszy czekać na pomoc, a nie zajmować pozycję roszczeniową. Dlaczego jednak to wołanie ma być groźne i mgliste? Co może być groźnego w głodzie słabej Nędzy? Może chodzi o niezaspokojenie nędzy, wielkość jej głodu. Dlatego jej wołanie jest mgliste, trudne do dokładnego określenia. Czego właściwie mogą chcieć nędzarze?

W pozytywistycznych wierszach prośba nędzy ma charakter sytuacyjny: żebranie o chleb czy lekarstwo, żebranie ograniczone czasowo do zaspokojenia głodu czy innej potrzeby ${ }^{7}$. Redukcja biedy proletariatu do żebraczej nędzy pozwala

\footnotetext{
${ }^{5}$ Ibidem, 18-24.

${ }^{6}$ Ksiega wierszy polskich XIX wieku, vol. III, ed. Julian Tuwim et Juliusz W. Gomulicki (Warszawa: Państwowy Instytut Wydawniczy, 1956), 132-143.

${ }^{7} \mathrm{Na}$ temat filantropii w literaturze pozytywistycznej pisała wyczerpująco Beata K. Obsulewicz-Niewińska, „Nieobałamucona” wrażliwość. Pisarze okresu pozytywizmu o filantropii i miłosierdziu (Lublin: Wydawnictwo KUL, 2008).
} 
zacieśnić problemy biednych do sytuacji skrajnych. Taki mechanizm wybiera Pilecki w wierszu Za ostatni grosz - nędza, największy wróg ludzkości, siła potężna i wielka zostaje ukonkretniona do sytuacji rodzinnej - ojciec-pijak, głodna matka i chore dziecko mieszkają w wilgotnej i zimnej ,,jamie grobowej”. Matka walczy z głodem, ale za ostatnie pieniądze nie kupuje jedzenia, lecz lekarstwo otrzymane dzięki życzliwości aptekarza po mocno zniżonej cenie. Wtedy dopada ich ojciec rodziny, rozwścieczony wydaniem pieniędzy - uliczną awanturę rodziny przerywa interwencja służb porządkowych, wszyscy trafiają do więzienia. Pilecki zbudował historię ze schematycznych obrazków - „Na rękach dziecię trzyma matka nieszczęśliwa”, „Dla nędzy wygłodniałej rozkoszne zjawisko / Na wystawie sklepowej... Jak straszne męczarnie! / Głód szarpie pierś zbolałą - a tu wzrok się garnie / Do strawy..." tulącej chore dziecko do piersi, biedaka przed niedostępną żywnością, pijaka, który wyzywa i bije swoją żonę. $Z$ tych klisz Pilecki buduje stereotypowe przedstawienie biedy, która może wywołać litość, ale nic więcej - odbiorca znajduje się tak daleko od niej, że nie ma tu ani możliwości empatii, ani zagrożenia biedą, raczej pojawia się dystans do „żądz nieczystych” i „zgnilizny uczuć”.

Najpełniejszy obraz proletariackiej nędzy rozwija Maria Konopnicka, według określenia Kazimierza Kelles-Krauza poetka proletariatu. Narodziny jej poezji chronologicznie zbiegają się z powstaniem ruchu robotniczego ${ }^{9}$, a tematem wielu jej wierszy i opowiadań są losy najbiedniejszych przedstawicieli proletariatu wiejskiego i miejskiego: dzieci, sierot, bezrobotnych i więźniów ${ }^{10}$. Wśród najważniejszych jej wierszy znajduje się popularny w ruchu socjalistycznym Wolny najmita przedstawiający wyłącznie negatywną wolność wyzwolonego z pańszczyzny chłopa, którego podatki zmuszają do opuszczenia malutkiego gospodarstwa. Od czego uwolnił się chłop? Na pewno od ziemi, także od rodziny, od wszelkich więzów łączących go z tradycją. Choć Konopnicka mocno podkreśla nędzę wolnego najmity, Kelles-Krauz zauważa, że:

Nie chce ona poezji przemienić w siostrę miłosierdzia, kładącą na olbrzymie rany - małe plasterki filantropii i modłów: nie rozczula się ona jeno nędzą [...] - widzi ona przed sobą potężne kategorie ekonomiczne, rozumie całą doniosłość ich walki klasowej, widzi przed sobą cały ustrój społeczny zły i niesprawiedliwy i przeczuwa burzę i rewolucję ${ }^{11}$.

${ }^{8}$ Antoni Pilecki, Poezye, 19.

${ }^{9}$ Kazimierz Kelles-Krauz, Marya Konopnicka, poetka proletaryatu (Kraków: J. Fischer, 1902); Marian Stępień, Rodowód. Studia nad socjalistyczna krytyka literacka w Polsce do roku 1918 (Kraków: Wydawnictwo Literackie, 1983), 262.

${ }^{10}$ Barbara Bobrowska zwraca uwagę na zbieżność poezji Konopnickiej z postulatami krytyki literackiej wczesnego pozytywizmu. Barbara Bobrowska, „Elementy naturalizmu w «Obrazkach» Marii Konopnickiej”, in Problemy literatury polskiej okresu pozytywizmu, seria III, ed. Edmund Jankowski, Janina Kulczycka-Saloni (Wrocław, Warszawa, Kraków, Gdańsk, Łódź: Zakład Narodowy im. Ossolińskich, 1984), 119.

${ }^{11}$ Kazimierz Kelles-Krauz, op. cit., 16. 
Ten efekt powstaje dzięki kontrastowi między demokratycznymi i liberalnymi hasłami czasów kapitalizmu, odwołującymi się do różnych form wolności, a obrazami zniewolenia wytwarzanego przez kapitalistyczny wyzysk. Wolny najmita wyrwany z zależności feudalnej wpaść musi w nową formę zależności, nową nędzę, często głębszą od tej z czasów pańszczyzny. Jakby dalszy ciąg historii chłopa przekształconego już w robotnika fabrycznego opowiada wiersz Sobotni wieczór. Uwolniony od roli chłop zostaje zniewolony przez maszynę, która nie opuszcza go nawet po opuszczeniu fabryki, gdyż „Myśl jego, wtłoczona pomiędzy koła i śruby, i piły / Była tak ciężka jak jego ramiona, / Co się bezwładnie wzdłuż ciała zwiesiły"12. Zmęczone ciało, głowa zwieszona, oblicze wygasłe pragnie jednak innego niż pijacki wypoczynku - rozmowy. Ale jedynym miejscem, do którego trafia, okazuje się szynk. Gdzie tkwi według poetki problem? W braku steru, braku ludzi z innej sfery, którzy zechcieliby wydobyć robotnika $\mathrm{z}$ rytmu automatycznej pracy i bezmyślnego pijaństwa. Tu, tak jak w wielu innych miejscach, Konopnicka uniewinnia nędzę - robotnik pije, bo nie ma alternatywy, którą powinni stworzyć mu choćby inteligenci.

Retoryka niewinności i związanego z nią współczucia dla ofiar kapitalizmu rozwinie się najpełniej w wierszach $\mathrm{z}$ bohaterami dziecięcymi. Przybywająca do miasta, „ciemnego mrowiska nędzarzy” dziewczynka z wiersza $C z y$ zginie? ma przed sobą drogę spodlenia, ,jak poszło tysiące" ${ }^{13}$. Tę drogę przeszła już kwiaciarka z Dwóch wiosen - w jej zachowaniu i postawie „Znać było, że już nie ma na tym świecie / Dla tego dziecka żadnej tajemnicy... / Że zna pokusy i nędzy, i grzechu"14. Konopnicka zarazem obarcza tę postać winą i ją uniewinnia, przerzucając winę za jej demoralizację na nędzę i życie, które „bezwstydne jest wobec nędzarzy!"15. Skontrastowanie obrazu dziewczyny z czystością kwiatów wyhodowanych w „cieplarnianych” warunkach mocno podkreśla wpływ warunków wychowania na moralny charakter jednostki.

Osądzanie i uniewinnianie biedy najpełniej pozwala rozwinąć metaforyka sądowa. Wiersz Konopnickiej Przed sądem ${ }^{16}$ przedstawia sytuację obwinionego wiejskiego sieroty, potomka nędzarzy, który samotnie staje przed sądem. Ale ta relacja ulega odwróceniu w nagłej wizji sędziego:

Jakby ta sala pusta była tronem,

Nad którym przyszłość z czołem zachmurzonem

Zasiada, pełna klęsk i spustoszenia...

${ }^{12}$ Maria Konopnicka, Poezje, ed. Alina Brodzka (Warszawa: „Czytelnik”, 1963), 98.

${ }^{13}$ Ibidem, 108.

${ }^{14}$ Maria Konopnicka, Poezye w nowym układzie. Tom IV. Obrazki (Warszawa: „Gebethner i Wolff", 1903), 62.

${ }^{15}$ Ibidem, 64.

${ }^{16}$ Podobne problemy pojawiają się w opowiadaniu Konopnickiej Pod prawem. 
I jakimś grzmiącym i ogromnym słowem

Oblicza plony na polu jałowem,

Przed sąd wzywając całe pokolenia...

I widział, jak szły gęste, ciemne thumy

I tamowały ruch globu w błękicie...

I spostrzegł, pełny trwogi i zadumy,

Że były chmurą ogromną o świcie,

Przez którą przebić nie mogło się słońce,

I zmierzch nad ziemią trwał przez lat tysiące...

Widział, że tłum ten - to siła stracona

Dla wielkich celów i dążeń ludzkości,

I czytał w groźnym spojrzeniu przyszłości,

Że chce rachunku - z miliona...

I ujrzał nagle, że wydziedziczeni

Za społeczeństwa swego cierpią winy... ${ }^{17}$

Przyszłość rozlicza tu kolejne pokolenia z historii rozumianej jako społeczna katastrofa, w której miliony wydziedziczonych żyją w nędzy i poniżeniu. Tłum nędzarzy tak się powiększa, że nastaje epoka zmierzchu, ciemności, gdyż historia zatrzymuje nawet naturę, skoro thumy tamują ruch globu. Konopnicka widzi ratunek dla tej apokaliptycznej wizji w edukacji ${ }^{18}$ - to ona ma zapobiec nastaniu ciemności i sprawić, by wydziedziczeni nie cierpieli za całe społeczeństwo. Sierota z oskarżonego staje się zatem ofiarą, której należy pomóc. Ceną tego uniewinnienia jest milczenie podsądnego - milczy, jedynie płacze, przemawia swoim wychudzonym ciałem. A cała dialektyka winy rozgrywa się w umyśle sędziego, „symbolu apelującym do sumienia inteligencji”"19. To w jego mocy jest zapobiec nędzy chłopca, to on ma odwrócić bieg historii.

Zauważmy, że wizja historii zbliża się tu do obrazu dziejowej katastrofy w dziewiątej Tezie historiozoficznej Waltera Benjamina ${ }^{20}$, gdzie także mamy do czynienia ze spojrzeniem na historię z punktu widzenia przyszłości. Anioł historii nie może jednak niczego zmienić, niczego zrobić, gdyż w jego skrzydła wieje wiatr postępu. Pozostaje mu zatem kontemplacja dziejowej i naturalnej katastrofy. Alegorie nędzy muszą zatrzymać się na granicy działania - ustanawiają podwójną bierność nędzarza i obserwatora, którzy mogą tylko percepować aktywność upodmiotowionej nędzy, wyniszczającej kolejne pokolenia biedaków. Wyjście z tej pasywności umożliwia podwójna zmiana. W rzeczywistości musi powstać organizacja nędzarzy, a w poetyce alegorię zastąpić powinien symbol.

${ }^{17}$ Maria Konopnicka, Poezje, 105-106.

${ }^{18} \mathrm{O}$ edukacyjnym kontekście wiersza zob. Tadeusz Budrewicz, Wiersze pozytywistów. Interpretacje (Katowice: Książnica, 2000), 155.

${ }^{19}$ Alina Brodzka, O nowelach Marii Konopnickiej (Warszawa: Państwowy Instytut Wydawniczy, 1958), 294.

${ }^{20}$ Walter Benjamin, „Tezy historiozoficzne”, in idem, Konstelacje. Wybór tekstów, trans. Adam Lipszyc et Anna Wołkowicz (Kraków: Wydawnictwo Uniwersytetu Jagiellońskiego, 2012), 316. 


\section{Symboliczne upodmiotowienie w poezji rewolucyjnej}

Wraz z pojawieniem się ruchu socjalistycznego powstaje polska poezja rewolucyjna. Do jej funkcji należy nie tylko wyrażanie nowych idei wyzwolenia proletariatu, nauczanie „rewolucyjnego abecadła” ${ }^{21}$ w czasach, gdy brakuje broszur i książek do przekazania socjalistycznych teorii. Poprzez te wiersze dokonuje się agitacja, wykształca się poczucie wspólnoty, podzielanych znaków i toposów. Wspólne śpiewanie i recytacja ustanawiają tożsamość grupy robotników postawionych w mocnej opozycji do kapitalistów, fabrykantów, wyzyskiwaczy oraz wspierającego ich cara i administracji rosyjskiej.

Co nowego dzieje się w tych wierszach? W przeciwieństwie do poezji pozytywistycznej wiersze socjalistyczne nie ograniczają się do przedstawienia nędzy proletariatu: oczywiście nie zakrywają robotniczej biedy, przeciwnie, często ją eksponują. Ale nędza nie kończy tu przedstawienia, które miałoby wywołać filantropijną litość mieszczańskiego odbiorcy. Brakuje tu motywacji „humanitarno-etycznej" 22 , a w jej miejsce pojawia się idea proletariackiej sprawiedliwości społecznej. Nędza zostaje upodmiotowiona - to liryczny podmiot zbiorowy jej doświadcza, ale nie jako fatum, losu, nieszczęścia, lecz jako wyzysku, krzywdy klasowej, która zlikwiduje rewolucja. Poezja rewolucyjna dąży do akumulacji krzywdy, by stała się gniewem, nienawiścią klasową ${ }^{23}$. Dzięki tej akumulacji ma powstać afektywny kapitał rewolucyjny - poczucie zbiorowej siły, zdolnej do zniszczenia starego porządku i budowy nowego świata. Spróbujmy prześledzić kolejne etapy dziania się rewolucji w poezji.

Poezja rewolucyjna nie rezygnuje z przedstawienia nędzy, ale zmienia sposób jej ukazywania. Niewiele znajdzie się tu konkretnych historii nędzarzy jak u Pileckiego czy Konopnickiej. Zamiast ukazywania nędzy poprzez historię biedaków, często lumpenproletariuszy, dzieci, najlepiej sierot, wybiera się uogólniony schemat nędzy - od razu łączony z jej przyczynami. Tradycyjny obraz nędzy - żebractwa - zostaje w wierszu Nędza niegdyś a dziś skonfrontowany $\mathrm{z}$ nędzą proletariatu, który już nie prosi, nie okazuje pokory, nie bije pokłonów, lecz „Z mocą swe żądania / Stawiać się poważy”24. Obrazy służą nie tyle do wywołania współczucia, co do uświadomienia nędzy jako efektu systemu kapitalistycznego oraz możliwości jej pokonania dzięki wspólnej sile proletariatu.

${ }^{21}$ Józef Kozłowski, Śpiewy proletariatu polskiego (Kraków: Polskie Wydawnictwo Muzyczne, 1977), 13.

${ }^{22}$ Bogdan Zakrzewski, Czegóż chca oni. Wiersze i pieśni w kręgu Wielkiego Proletariatu (Warszawa: „Książka i Wiedza”, 1989), 60.

${ }^{23}$ Peter Sloterdijk, Gniew i czas. Esej polityczno-psychologiczny, trans. Arkadiusz Żychliński (Warszawa: Wydawnictwo Naukowe Scholar, 2011).

${ }^{24}$ [Anonim], „Nędza niegdyś a dziś”, in Polska poezja rewolucyjna 1978-1945, ed. Stefan Klonowski (Warszawa: Państwowy Instytut Wydawniczy, 1977), 87. 
Nędza robotnicza powstaje nie tylko z braku pracy, ale też mimo pracy - wiersz Dlaczego? przedstawia efekty pracy kolejnych zawodów zawłaszczane przez kapitalistów, a dla robotników zostaje „Głód, nędza, starość i choroba”25. Wyliczenia krzywdy: „Patrz, pod knutem brat twój kona, / A tam siostra twa zgwałcona, / Tu twe dzieci z głodu giną, / A tu ojciec twój zbiedzony" ${ }^{26}$ służą do pokazania konieczności buntu. Wystarczy się zjednoczyć - brak jedności to samozawiniona ${ }^{27}$ słabość proletariatu, który dysponuje siłą i mocą, ale nie potrafi jeszcze jej użyć. Nędzę często pokazuje się na granicy śmierci - topika żywych trupów („trupy na wpół żywe” ${ }^{28}$; „młodość w mogile przeżyła” ${ }^{29}$ ) rozwija się w topikę zmartwychwstania: „To już biedacy powstają, / Łamią trumny wieko. / Oj. Trumnę łamią żelazną, / Co ich trzymała w niewoli” ${ }^{30}$. Proletariusze jako żywe trupy mają się przebudzić, by wspólnie walczyć o wyzwolenie.

W poezji rewolucyjnej zaczyna się pojawiać wyraźny obraz wrogów proletariatu $^{31}$. To przede wszystkim fabrykanci często pokazywani w trakcie spożywania efektów pracy wyzyskiwanego proletariatu. Anonimowy wiersz Hulajcie! Jaśnie wielmożnym panom na karnawat ${ }^{32}$ przedstawia zabawę karnawałową w opozycji do nędzy i poniżenia społeczeństwa. Takie obrazy mają wzbudzić nieufność do stabilnego podziału świata na bogatych i biednych, rozwinąć negatywne afekty do luksusu, którego drugą stroną jest nędza proletariatu. W tytułowym wierszu pierwszego zbioru poezji socjalistycznej Wacław Sieroszewski wspomina złoto, wino i prostytucję jako elementy burżuazyjnego luksusu opartego na hedonizmie („Użyjmy świata!) oraz darwinizmie („on słaby! W walce o byt / Mogą się ostać tylko siłacze / Jak my"). Zwierzęca siła, energia trwonienia zagrabionych bogactw ma legitymizować posiadanie kapitału i jego użycie. Proletariusze to w tej narracji słabi, którzy przegrali walkę o byt i pozostaje im ciężka praca. Poezja rewolucyjna próbuje przełamać tę socjaldarwinowską narrację w kilku punktach. Przede wszystkim mocno atakuje dogmat o świętości pracy wykonywanej w pokorze i podporządkowaniu. Praca robotników skutkuje

${ }^{25}$ [Anonim], „Dlaczego?”, in Polska poezja rewolucyjna, 94.

${ }^{26}$ [Anonim], ,*** (Urywek z większej całości)”, in Polska poezja rewolucyjna, 25.

${ }^{27}$ Metaforyka samozawinionej niedojrzałości konceptualizuje ważny proces rozszerzania mieszczańskiego oświecenia na proletariat. O idei samozawinionej niedojrzałości: Immanuel Kant, Odpowiedź na pytanie: czym jest Oświecenie?, trans. Tomasz Kupś, in idem, Dzieła zebrane. Tom VI. Pisma po roku 1781, ed. Marek Jankowski, Tomasz Kupś, Milena Marciniak, Mirosław Żelazny (Toruń: Wydawnictwo Naukowe Uniwersytetu Mikołaja Kopernika, 2012), 45; Manfred Sommer analizuje wszechstronnie metaforykę dojrzałości w artykule „Mündigkeit: Begriff und Metapher”, in idem, Identität im Übergang: Kant (Frankfurt am Main: Suhrkamp Verlag, 1988).

${ }^{28}$ [Anonim], „Gdzie wy, dzieci?...”, in Polska poezja rewolucyjna, 77.

${ }^{29}$ [Anonim], „Chorał”, in Polska poezja rewolucyjna, 83.

${ }^{30}$ [Anonim], „Oj, nie było... (Na nutę: Oj, hozard, zaporożci...)”, in Polska poezja rewolucyjna, 34.

${ }^{31}$ Bogdan Zakrzewski, op. cit., 23. O dychotomii klasowej w poezji rewolucyjnej vide Tadeusz Bujnicki, op. cit., 14-15.

${ }^{32}$ Polska poezja rewolucyjna, 75-76. 
coraz większym zniewoleniem, proletariat sam kuje dla siebie kajdany, podtrzymując swoją pracą system kapitalistycznego wyzysku.

Wyraźne rozpoznanie konfliktu klasowego, także poprzez łatwe do spopularyzowania obrazy niesprawiedliwego luksusu, pociąga za sobą odrzucenie reformistycznych programów rozwiązania konfliktu między kapitałem a pracą. W wierszu Hymn liberalny na rok 1880 w oczekiwaniu konstytucji Wacław Święcicki wykpiwa liberalne mieszczaństwo i „plaster pracy organicznej”, przypisując pozytywistom sojusz z rosyjską administracją: „Świat kapitalnie przereformujemy/ Z twą konstytucją - naszym kapitałem" ${ }^{33}$ - te reformy mają polegać między innymi na wieszaniu socjalistów. Powtarzanie, że „Trud nas nie zbawi, bo naszą pracą / Dziś panowie się tylko bogacą" ${ }^{34}$ podkreśla, że robotnicy nie wierzą już, że dzięki pracy i oszczędności sami mogą stać się właścicielami i kapitalistami.

Poezja rewolucyjna wychodzi zatem od obrazowego uchwycenia konfliktu klasowego - pokazania nędzy proletariuszy oraz luksusu burżuazji. W ten statyczny obraz struktury społeczeństwa klasowego wprowadza jednak dynamikę walki klasowej, której sama staje się częścią. To właśnie w pieśniach robotniczych ma się dokonać uświadomienie mas proletariatu, to tu robotnicy mają poczuć swoją moc i siłę, by stać się zdolnymi do działania. Nowa topika siły będzie fundowała obraz proletariatu zjednoczonego. Przytoczmy kilka takich apeli: „Ludu roboczy, poznaj swą siłę...”35; „Powstań, własne poznaj siły. / Wszak gdy zechcesz, na żądanie / Wszelki ruch na świecie stanie” ${ }^{36,}$ „Poznajmyż, żeśmy silni, że robocze ramię, / Gdy poczuje swą siłę tylko - wszystko złamie. / Poznajmyż, że nasz tryumf jest nieunikniony" ${ }^{37}$. Poezja rewolucyjna wprowadza ciekawą sytuację epistemiczną - podmiotem poznania jest proletariat, ma poznać swą siłę, choć na razie widzi głównie własną słabość, nędzę, krzywdę. Ma rozpoznać siebie jako zbiorowość, choć na razie dzieli się na wiele odłamów i jednostek. Samopoznanie proletariatu ma odmienić jego bycie - sprawić, że z bytu w sobie, który można opisywać w kategoriach biernej nędzy, stanie się bytem dla siebie, zdolnym do działania, sprzeciwu, rewolucji. Nadzieje na zbiorową siłę zaczną się spełniać w czasie demonstracji pierwszomajowych - poczucie siły zostanie uwidocznione w zatrzymanych fabrykach „Głuche stoją fabryk rzędy, / Fabrykanci też świętują. / My nadajem światu pędy, / Jak zagramy, tak tańcują. / Teraz znamy już swą siłę”, „Bośmy siły swe poczuli. / Siły czujem!...”38.

${ }^{33}$ Wacław Święcicki, „Hymn liberalny na rok 1880 w oczekiwaniu konstytucji”, in Polska poezja rewolucyjna, 46.

${ }^{34}$ [Anonim], „Kolęda robotnicza (Na nutę: Wśród nocnej ciszy głos się rozchodzi, Wstańcie, pasterze, bo wilk nadchodzi...)", in Polska poezja rewolucyjna, 135.

${ }^{35}$ [Anonim], „Ludu roboczy, poznaj swą siłę...”, in Polska poezja rewolucyjna, 107.

${ }^{36}$ Bolesław Czerwieński, „Do robotników! (Podług Herwegha)”, in Polska poezja rewolucyjna, 49.

${ }^{37}$ Bolesław Czerwieński, „Do braci robotników”, in Polska poezja rewolucyjna, 60-61.

${ }^{38}$ [Anonim], „Ufni w przyszłość”, in Polska poezja rewolucyjna, 111. 
Zatrzymany świat pokazuje siłę proletariatu, która nie polega na przemocy, aktywnym niszczeniu, ale na zaprzestaniu pracy. Strajk generalny, opisywany przez Sorela ${ }^{39}$ i Benjamina ${ }^{40}$ miał właśnie polegać na biernej przemocy - proletariat, zwykle widziany jako słaby, poznaje zatem swą siłę nie tylko w obrazach silnych robotników, ale przede wszystkim w swojej bezczynności, która wywołuje bierność całego świata. Obraz zatrzymania produkcji, służącej tylko przedłużeniu zniewolenia proletariatu, pokazuje także specyficzną filozofię czasu, bliską doświadczeniu mesjańskiemu. Czerwieński pisze, że „nadchodzi chwila" ${ }^{41}$ - czas aktualny ogląda się z perspektywy czasu przyszłego: który rozpada się na czas rewolucyjnej chwili oraz czas nowego świata. Ten czas ma odczuwać nie tylko proletariat, ale też burżuazja - oprócz poczucia bezpiecznej przewagi zaczyna bowiem odczuwać, że ich czas mija („Drżą! Bo widzą moc swą w grobie..." ${ }^{42}$ ). Jakby kompensacją za doznane krzywdy klasowe, a także więzienne są liczne obrazy sądu i zemsty, które dokonają się w czasie rewolucji.

Według Tadeusza Bujnickiego poezja rewolucyjna „stworzyła nową formułę zbiorowego podmiotu i zbiorowego bohatera. Romantyczny «lud» stał się "proletariatem», o wyraźnej cesze podmiotowości" ${ }^{43}$. To zbiorowość jeszcze słabo określona, najczęściej wskazywana zaimkami w pierwszej osobie liczby mnogiej. Nieokreśloność zaimków pozwala połączyć podmiot liryczny i bohatera (czyli proletariat) w jedną zbiorowość ${ }^{44}$. Bardziej indywidualne apele („Wstań”, „Zbudź się”) jakby roztapiają się w apelach do zbiorowości.

Konkretyzacją biernej siły proletariatu było zatrzymanie fabryk w czasie strajków czy święta pierwszego maja, a konkretyzacją proletariackiej zbiorowości może być pochód, manifestacja. Bycie na manifestacji to przede wszystkim niebycie w pracy, porzucenie swoich codziennych obowiązków - razem $\mathrm{z}$ wieloma innymi osobami. Sama obecność staje się już znakiem sprzeciwu, samowolnego porzucenia miejsca pracy, które pozostało puste. Maszerowanie w pochodzie, obecność na manifestacji pełni zatem funkcję medium łączącego cielesną obecność robotników z sensem nieobecności w miejscu przeznaczonym dla proletariusza ${ }^{45}$.

${ }^{39}$ Georges Sorel, Rozważania o przemocy, trans. Marek J. Mosakowski (Warszawa: Wydawnictwo Krytyki Politycznej, 2014).

${ }^{40}$ Walter Benjamin, „Przyczynek do krytyki przemocy”, in idem, Konstelacje.

${ }^{41}$ Bolesław Czerwieński, „Do braci robotników”, in Polska poezja rewolucyjna, 61.

${ }^{42}$ [Anonim], *** (Urywek z większej całości), in Polska poezja rewolucyjna, 26.

${ }^{43}$ Tadeusz Bujnicki, O poezji rewolucyjnej, 16.

${ }^{44}$ Ibidem, 20.

${ }^{45}$ Wiele ważnych artykułów o dziewiętnastowiecznych demonstracjach znajduje się w książce Massenmedium Strasse: zur Kulturgeschichte der Demonstration, ed. Bernd Jürgen Warneken (Frankfurt am Main, New York: Campus-Verlag, 1991). 
Ta medialna obecność ustanawia nową syntezę ciał połączonych łańcuchem $\mathrm{raqk}^{46}$, a nie kajdanami - więziennymi czy ekonomicznymi - przykuwającymi do stanowiska w fabryce i społeczeństwie. Pochód czy manifestacja potrzebują jednak dopełnienia z znakach, symbolach, rytuałach: wspólnym śpiewie, niesionym sztandarze. Józef Kozłowski pisze, że:

W środowisku robotniczym pieśń robotnicza pojawia się niejako spontanicznie, ale śpiewający natychmiast podporządkowują się potędze jej słów i melodii. Dzięki niej bezkształtny tłum zmienia się w zespoloną jednolitą wolą społeczność, w kolektyw, bo właśnie zespołowy śpiew przydaje robotniczemu zgrupowaniu odświętnego, uroczystego wyrazu i sprzyja osiągnięciu zamierzonego celu nawet przypadkowo zebranej grupie robotników ${ }^{47}$.

Takimi śpiewami stały się przede wszystkim Czerwony sztandar oraz Warszawianka. W książce Sztandar i krew Bogdan Zakrzewski zinterpretował te pieśni, wiążąc ich treść z miejscem wykonania i ukazując ich performatywną moc powoływania zbiorowości. O Czerwonym sztandarze pisze: „Ta hymniczna, patetyczna fraza o zaskakującej strukturze fonicznej otwiera jakby i rozpoczyna potężny zbiorowy śpiew odbywającej się manifestacji robotniczej"48, a Warszawianki

inicjalna funkcja [...] wyraża się w przewodnictwie rewolucyjnemu pochodowi, manifestacji proletariackiej. On wprowadza bezpośrednio swym wielorakim znaczeniem emblematycznym w ich klimat i „meliczną obecność”. [...] „Śmiało!”, co ma od razu zagrzewać do walki i zapowiedzieć jej słuszność, zaskoczyć nagłością działania, wprowadzić jakby w wir walki, bez zapowiedzi, bez przygotowania ${ }^{49}$.

Wspólny śpiew, wzniesienie czerwonego sztandaru mają zjednoczyć nędzarzy w silny proletariat. A to już oznacza początek, dzianie się rewolucji, o której mówi pieśń i w którą może przekształcić się pochód „na ulicach miasta, które są jakby wypełnione nurtem nie dającego się wstrzymać «strumienia» manifestantów-robotników" ${ }^{50}$. Proletariat walczy o swoją widzialność w mieście, o to żeby stał się widoczny dla samego siebie - a także dla swoich wrogów, którym obiecuje zemstę ${ }^{51}$.

${ }^{46}$ Bogdan Zakrzewski interpretuje fragment Czerwonego sztandaru „z dłonią w dłoń” jako „archetypowy emblemat łańcucha czy zaklęcia (często związkowego) przyjaźni i nierozerwalnej więzi ideowej”. Cf. Bogdan Zakrzewski, Sztandar i krew. Studia monograficzne o najgłośniejszych pieśniach Wielkiego Proletariatu (Wrocław: Zakład Narodowy imienia Ossolińskich, 1982), 31.

${ }^{47}$ Józef Kozłowski, op. cit., 11.

${ }^{48}$ Bogdan Zakrzewski, Sztandar i krew, 23.

${ }^{49}$ Ibidem, 94.

${ }^{50}$ Ibidem, 31.

51 „Ideologiczne echa wydarzeń łódzkich były duże i ujawniły się w rozmaitych formach. Między innymi piosenki i wiersze popularne w środowisku robotniczym zaczęły tracić swój łzawo-cierpiętniczy ton, a stawały się bardziej mściwe i obfitujące w krwawe symbole. Pomału na pierwszy plan zaczął wysuwać się motyw zemsty i nienawiści, a klasowe wizje społeczeństwa zdobywały sobie zwolenników”. Elżbieta Kaczyńska, „Tłum a władza. Anatomia masowych ruchów społecznych w Królestwie Polskim na przełomie XIX i XX wieku”, in Przemoc zbiorowa, ruch masowy, rewolucja, ed. Elżbieta Kaczyńska et Zbigniew W. Rykowski (Warszawa: Wydawnictwa Uniwersytetu Warszawskiego, 1990), 76. 
Zatrzymajmy się przy refrenie Czerwonego sztandaru:

Dalej więc, dalej więc, wznieśmy śpiew.

Nasz sztandar płynie ponad trony,

Niosąc tam zemsty grom, ludu gniew,

Przyszłości rzucając siew,

A kolor jego jest czerwony,

Bo na nim robotnicza krew! ${ }^{52}$

Śpiew i sztandar jakby zamieniły się tu miejscami - Warszawianka rozpoczyna się od podniesienia sztandaru: „Śmiało podnieśmy sztandar nasz w górę”, podobny oczywisty gest ma miejsce w wielu innych wierszach. Czerwieński swoim tytułem wprowadza jednak samozwrotne zamieszanie - Czerwony sztandar to pieśn, a zarazem widzialny znak. Synteza tego, co słyszalne i widzialne wzmacnia obecność symbolu, która wprowadza jedność śpiewających ciał, zespojonych w „chóralnej groźbie" ${ }^{33}$. Medialna synteza komunikuje bowiem afekty gniewu, zemsty. Zakrzewski pisze o afektywnych oddziaływaniach Warszawianki:

Profuzja owych haseł, wykrzykników, wezwań, sloganowej frazeologii, mimo ich pospolitości robi wrażenie, oddziałując swym donośnym, umasowionym, frenetycznym natarciem, jak manifestacyjny atak zrewolucjonizowanych mas ludowych. Efekty rewolucyjnych działań: zrywanie, niszczenie, burzenie, topienie emblematów dawnej władzy: straszna zemsta, wymierzanie krwawej kary „dzisiejszym katom” oddziałują brutalną energią, silnymi bodźcami na wyobraźnię śpiewającego kolektywu ${ }^{54}$.

Zobowiązaniem do zemsty staje się robotnicza krew. Wspomnieliśmy już o rezurekcyjnych treściach poezji rewolucyjnej. Jochen Hörisch uznaje eucharystię, obecność ciała i krwi zmartwychwstałego Chrystusa w chlebie i winie za jedno z przewodnich mediów kultury europejskiej ${ }^{55}$. W przypadku proletariatu ten rezurekcyjny scenariusz powtarza się $\mathrm{w}$ zmodyfikowanej postaci. Również proletariat wydaje się półżywy, prawie martwy z powodu swojej nędzy. Jego powstanie, przebudzenie ma charakter rezurekcji - czegoś niemożliwego, co szczególnie w racjonalnym świecie kapitalizmu nie powinno się wydarzyć. Zmartwychwstałe ciało proletariatu cały czas jednak krwawi - dalej trwa wyzysk, a walka domaga się ofiar, ciał torturowanych w więzieniach, fabrykach, a także krwi przelewanej na demonstracjach. Robotnicza krew, obecna symbolicznie na czerwonym sztandarze, cały czas jest, albo może stać się także obecna realnie. Już nie jako krew nędzy, ale jako krew sakralizowanych ofiar.

\footnotetext{
${ }^{52}$ Bolesław Czerwieński, „Czerwony sztandar”, in Polska poezja rewolucyjna, 50.

${ }^{53}$ Bogdan Zakrzewski, Sztandar i krew, 23.

${ }^{54}$ Ibidem, 105.

${ }^{55}$ Jochen Hörisch, Brot und Wein. Die Poesie des Abendmahls (Frankfurt am Main: Suhrkamp Verlag, 1991).
} 
Poezja rewolucyjna konstruuje zatem nowy obraz robotnika, którego słabość i nędza zostają przekształcone w siłę i moc. Proletariat nie podejmuje aktywnej walki zbrojnej, nie wywołuje powstania, lecz przygotowuje rewolucję, zburzenie całego starego świata, by na jego gruzach zbudować nowy ład. Umocnieniem przekonań o sile słabego proletariatu są także opisy jego znaczenia dla narodu: pisze o tym Czerwieński („Poznajmy, że robotnik, choć dziś ginie z głodu, / Jest jedyną podstawą każdego narodu" ${ }^{\prime 56}$ ), ale przede wszystkim Andrzej Niemojewski. Przemysłowe Zagłębie z jego cyklu Polonia irredenta to rejon kraju, z którego uszły wszystkie stare grupy społeczne, a walkę z międzynarodowym kapitałem toczy jedynie słaby proletariat, ale to w nim „nowa Polska wstanie!”57, gdy poczucie wielkiej krzywdy przeobrazi się w erupcję wulkanu.

\section{Zakończenie}

Gdy Walter Benjamin pisze, że „Alegoria to armatura nowoczesności”, a w innych pracach opracowuje pojęcie alegorii służące do analizy barokowego rozpadu świata czy dziewiętnastowiecznej gospodarki towarowej, może się wydawać, że dla rozumienia nowoczesności użycie pojęcia symbolu jest zbędne - przecież to alegoria pozwala rozpoznać semiotykę kapitalizmu. Ten krytyczny aspekt pojęcia alegorii trudno przecenić ${ }^{59}$. Właśnie alegoria może pokazać utowarowioną rzeczywistość kapitalizmu, np. sprowadzenie rzeczy do towarów, przeliczanie wszystkiego na wartości wymienne. Alegoria jako sposób przedstawienia stabilizuje tę wymianę towarową. W przypadku przedstawienia proletariatu, poeta poprzez alegoryczne obrazy biedaków sprowadza proletariat do siły roboczej, którą ktoś powinien nabyć, dać pracę, edukację, by przystosować sierotę albo bezrobotnego do kapitalistycznego świata. Alegoria nie proponuje jednak żadnej możliwości oporu. Czyni to dopiero symbol, który obiecuje nieskończoną totalność, znaczenie całościowe i uniwersalne ${ }^{60}$ oraz przemianę świata w konfigurację symboli. To właśnie „metafizyczne tło symbolu” ${ }^{1}$ umożliwia wytworzenie nowych podmiotowości, które ustanawiają się na przykład w czasie

${ }^{56}$ Bolesław Czerwieński, „Do braci robotników”, in Polska poezja rewolucyjna, 60.

${ }^{57}$ Andrzej Niemojewski, Wybór wierszy, ed. Marian Piechal (Warszawa: Państwowy Instytut Wydawniczy, 1983), 51.

${ }^{58}$ Walter Benjamin, Twórca jako wytwórca, trans. Robert Reszke (Warszawa: Wydawnictwo KR, 2011), 193.

${ }^{59} \mathrm{O}$ symbolu, alegorii i fetyszyzmie w kontekście tradycji marksistowskiej vide Jochen Hörisch, Orzet czy reszka. Poezja pieniadza, trans. Jadwiga Kita-Huber et Steffen Huber (Kraków: Universitas, 2010), 265.

${ }^{60}$ Paul De Man, „Retoryka czasowości”, trans. Andrzej Sosnowski, Literatura na Świecie, no. 10-11 (1999): 192.

${ }^{61}$ Hans-Georg Gadamer, Prawda i metoda. Zarys hermeneutyki filozoficznej, trans. Bogdan Baran (Kraków: inter esse, 1993), 97. 
manifestacji robotniczych, gdy dotychczas skryci, widziani głównie jako żebracy, proletariusze stają się widoczni - dla innych, ale przede wszystkim dla siebie. W tej próbie zmiany podziału zmysłowości ${ }^{2}$, tkwi szansa na stworzenie nowej wspólnoty:

[...] defilada czy też pochód (tak jak święto) przekształca jedną lub wiele realnych i specyficznych relacji społecznych w communitas (zarazem czasową i symboliczną). Defilada, pochód, procesja przedstawiają tę transformację $\mathrm{i}$ - dodajmy - przedstawiając ją, urzeczywistniają ${ }^{63}$.

W przypadku poezji rewolucyjnej, która funkcjonuje zarazem jako pieśń śpiewana w czasie manifestacji czy tajnych spotkań, symboliczne treści mają jednoczyć śpiewających proletariuszy w nowy podmiot zdolny do podjęcia walki z wyzyskiem i do zmiany swojego położenia, a nawet do przebudowy całego społeczeństwa. Poezja rewolucyjna akcentując siłę nędzarzy, a nie siłę nędzy, dokonuje przemiany rozumienia czasu - konsekwencją alegoryzacji nędzy okazuje się bowiem historyczna katastrofa, osądzana z przyszłości jako wina zaniechanej filantropii i edukacji, natomiast poetyka symboliczna otwiera się na czas mesjański, w którym proletariat w pełni zmartwychwstanie.

\author{
ALLEGORIES AND SYMBOLS OF THE PROLETARIAT. \\ RHETORICS OF DESUBJECTIFICATION AND SUBJECTIFICATION \\ OF THE WORKING CLASS IN THE POETRY \\ OF THE SECOND HALF OF THE $19^{\text {TH }}$ CENTURY
}

\title{
Sum mary
}

The article describes two models of representing proletariat in the Polish poetry of the second half of the $19^{\text {th }}$ century. The first model relates to the image of misery, poverty and weakness and focuses on the frail beings (children, orphans, paupers) faced with the state apparatus or lack of any help from the environment. Various forms of allegories appear in this model very frequently. The second model can be seen in the so called revolutionary poetry. Here, the image of poverty and weakness starts to fulfill a completely different role - the misery of the proletariat is perceived not through the eyes of an outside observer, but by the proletariat itself, although only to see the strength of the weak coming from their number. The same reality is thus depicted in an absolutely different manner - in the first case the image confirms the misery and weakness of the proletariat which can only be changed by an outside philanthropist; in the second case the image induces the sense of empowerment in the proletariat, which - although weak, exploited and humiliated - possesses an inner power to recover from its position.

${ }^{62}$ Jacques Rancière, Dzielenie postrzegalnego. Estetyka i polityka, trans. Maciej Kropiwnicki et Jan Sowa (Kraków: Korporacja Ha!art, 2007).

${ }^{63}$ Louis Marin, O przedstawieniu, trans. Paweł Pieniążek et al. (Gdańsk: słowo/obraz terytoria, 2011), 68-69. 